http://www.sttpb.ac.id/e-journal/index.php/kurios

\title{
Iman Dan Perkembangan IPTEK Dikaitkan Dengan HIV/AIDS
}

\author{
Novie Pasuhuk \\ Sekolah Tinggi Teologi Pelita Bangsa Jakarta
}

\begin{abstract}
Abstrak
Makalah ini membahas mengenai HIV/AIDS dan strategi penanggulangannya dikaitkan dengan Ilmu Pengetahuan dan Teknologi (IPTEK). Berdasarkan pemicu yang telah diberikan, penulis mencoba merumuskan permasalahan yang terjadi, melalui pertanyaan-pertanyaan berikut: Apa yang terjadi jika masalah HIV/AIDS tidak segera di atasi? Mengapa kebijakan dan strategi penanggulangan HIV/AIDS itu penting? Strategi dan upaya apa saja yang dilakukan untuk penanggulangan HIV/AIDS? Bagaimana memutus rantai penyebaran penyakit itu? Apakah IPTEK itu sebaiknya di hindari? Penulisan ini bertujuan agar pembaca dapat memahami apa yang akan terjadi jika masalah HIV/AIDS ini tidak segera diatasi. Selain itu, pembaca mengetahui dan mengerti mengapa strategi-strategi penanggulangan HIV/AIDS itu penting. Pembaca dapat mengetahui bagaimana memutus rantai penyebaran penyakit ini. Pembaca dapat menentukan sikap bagaimana menyikapi IPTEK dengan pengaruh-pengaruh negatifnya. Lalu, pembaca dapat mengetahui apakah IPTEK itu sebaiknya di hindari atau tidak.
\end{abstract}

\section{Pendahuluan}

Kehidupan manusia tidaklah jauh dari kehadiran teknologi-teknologi dan alatalat yang modern dan canggih. Kehadiran teknologi-teknologi yang modern tersebut sangat membantu manusia dalam menjalani segala aktivitasnya. Misalkan saja seperti kehadiran televisi, telepon dan laptob serta internet yang membuat manusia menjadi dapat lebih mudah mengakses informasi-informasi dan kejadian-kejadian yang sedang terjadi diseluruh dunia serta membuat para manusia menjadi dapat berkomunikasi dengan lainnya dengan lebih mudah. Bandingkan saja ketika para manusia masih hidup dizaman dahulu, dimana segala sesuatu harus diperoleh dengan susah payah, kehidupan sekarang tampaknya jauh lebih menyenangkan karena hampir segala sesuatu yang kita inginkan dapat kita peroleh dengan mudah. Namun apakah kehadiran teknologiteknologi seperti itu dapat menjamin bahwa kehidupan manusia dapat menjadi 100 persen sejahtera? Jawabannya adalah tidak. 
IPTEK sering diiringi dengan pertambahan kriminalitas dan jumlah penyakit di dunia ini. SARS, Flu burung, HIV, merupakan contoh-contoh penyakit yang timbul seiring dengan perkembangan zaman. Selain itu, kejahatan-kejahatan seperti cyber crime, pembobolan bank, dsb terus bertambah, karena ada manusia yang menyalahgunakan teknologi untuk kepentingan dirinya sendiri. Secara singkat, kehadiran teknologi yang seharusnyaa mempermudah kehidupan manusia, malah berbalik menjadi pisau bermata dua yang membahayakan kehidupan manusia. IPTEK yang tidak memiliki standar moral justru akan digunakan untuk mempermudah suatu tindakan kejahatan. Dilihat dari perannya, memang ilmu pengetahuan telah banyak memberi sumbangan terhadap kepuasan jasmaniah manusia. IPTEK telah membantu manusia dalam menemukan solusi atas berbagai kesulitan hidup jasmaniah manusia. IPTEK telah membuat hidup manusia serba mudah dan praktis. Namun dari sudut kebutuhan jiwa, IPTEK ternyata tidak bisa memberi kepuasan. Justru disaat IPTEK mencapai puncaknya muncul semangat baru dalam manusia, yaitu semangat yang disebabkan kehausan akan kebutuhan rohani. Ilmu harus didasarkan pada iman dan bukan sebaliknya.

Jika ilmu didasarkan pada iman, maka hidup di dunia ini akan jauh lebih damai, sejahtera dan indah. Manusia menggunakan ilmu untuk mengagumi Tuhan yang menciptakan dan memelihara segala sesuatu. Contoh, ilmu astronomi, bumi diketahui selalu berotasi dan berevolusi dengan lintasan yang sama sehingga jarak bumi ke matahari selalu sesuai kebutuhan manusia. Jika ilmu didasarkan pada iman, maka apa yang dipelajari ini seharusnya memacu rasa syukur dan kagum kepada pencipta yang mengatur segalanya. Dengan IPTEK, manusia yang seluruh hidupnya didasarkan pada iman kepada Yesus akan menggunakan kemampuannya untuk membuat peralatan yang membantu sesamanya bukan membuat senjata atau reaktor nuklir yang menghancurkan sesama dan alam ciptaan Tuhan.

\section{Pengertian HIV dan AIDS}

\section{Apakah HIV?}

HIV merupakan singkatan dari 'human immunodeficiency virus'. HIV merupakan retrovirus yang menjangkiti sel-sel sistem kekebalan tubuh manusia (terutama CD4 positive T-sel dan macrophages - komponen-komponen utama sistem kekebalan sel), dan menghancurkan atau mengganggu fungsinya. Infeksi virus ini mengakibatkan terjadinya penurunan sistem kekebalan yang terus-menerus, yang akan mengakibatkan defisiensi kekebalan tubuh. 
Sistem kekebalan dianggap defisien ketika sistem tersebut tidak dapat lagi menjalankan fungsinya memerangi infeksi dan penyakit- penyakit. Orang yang kekebalan tubuhnya defisien (Immunodeficient) menjadi lebih rentan terhadap berbagai ragam infeksi, yang sebagian besar jarang menjangkiti orang yang tidak mengalami defisiensi kekebalan. Penyakit-penyakit yang berkaitan dengan defisiensi kekebalan yang parah dikenal sebagai "infeksi oportunistik" karena infeksi-infeksi tersebut memanfaatkan sistem kekebalan tubuh yang melemah.

\section{Apakah AIDS?}

AIDS adalah singkatan dari 'acquired immunodeficiency syndrome' dan menggambarkan berbagai gejala dan infeksi yang terkait dengan menurunn ya sistem kekebalan tubuh. Infeksi HIV telah ditahbiskan sebagai penyebab AIDS. Tingkat HIV dalam tubuh dan timbulnya berbagai infeksi tertentu merupakan indikator bahwa infeksi HIV telah berkembang menjadi AIDS. Perbedaan HIV dengan Aids adalah HIV tidak menimbulkan gejala yang terlihat atau dirasakan oleh penderita. Sementara Aids, penderita sudah merasakan infeksi-infeksi yang muncul sehingga orang tersebut perlu mendapatkan perawatan intensif di rumah sakit.

\section{Dampak buruk dari HIV/AIDS}

\section{Dampak terhadap demografi}

Salah satu efek jangka panjang endemi HIV dan AIDS yang telah meluas - seperti yang telah terjadi di Papua - adalah dampaknya pada indikator demografi. Karena tingginya proporsi kelompok umur yang lebih muda terkena penyakit yang membahayakan ini, dapat diperkirakan nantinya akan menurunkan angka harapan hidup. Karena semakin banyak orang yang diperkirakan hidup dalam jangka waktu yang lebih pendek, kontribusi yang diharapkan dari mereka pada ekonomi nasional dan perkembangan sosial menjadi semakin kecil dan kurang dapat diandalkan. Hal ini menjadi masalah yang penting karena hilangnya individu yang terlatih dalam jumlah besar tidak akan mudah dapat digantikan. Pada tingkat makro, biaya yang berhubungan dengan kehilangan seperti itu, seumpama meningkatnya pekerja yang tidak hadir, meningkatnya biaya pelatihan, pendapatan yang berkurang, dan sumber daya yang seharusnya dipakai untuk aktivitas produktif terpaksa dialihkan pada perawatan kesehatan, waktu yang terbuang untuk merawat anggota keluarga yang sakit, dan lainnya, juga akan meningkat. 


\section{Dampak Terhadap Sistem Pelayanan Kesehatan}

Tingginya tingkat penyebaran HIV dan AIDS pada kelompok manapun berarti bahwa semakin banyak orang menjadi sakit, dan membutuhkan jasa pelayanan kesehatan. Perkembangan penyakit yang lamban dari infeksi HIV berarti bahwa pasien sedikit demi sedikit menjadi lebih sakit dalam jangka waktu yang panjang, membutuhkan semakin banyak perawatan kesehatan. Biaya langsung dari perawatan kesehatan tersebut semakin lama akan menjadi semakin besar. Diperhitungkan juga adalah waktu yang dihabiskan oleh anggota keluarga untuk merawat pasien, dan tidak dapat melakukan aktivitas yang produktif. Waktu dan sumber daya yang diberikan untuk merawat pasien HIV dan AIDS sedikit demi sedikit dapat mempengaruhi program lainnya dan menghabiskan sumber daya untuk aktivitas kesehatan lainnya.

\section{Dampak Terhadap Ekonomi Nasional}

Mengingat bahwa HIV lebih banyak menyakiti orang muda dan mereka yang berada pada umur produktif utama (94\% pada kelompok usia 19 sampai 49 tahun), epidemi HIV dan AIDS memiliki dampak yang besar pada angkatan kerja, terutama di Papua. Epidemi HIV dan AIDS akan meningkatkan terjadinya kemiskinan dan ketidak seimbangan ekonomi yang diakibatkan oleh dampaknya pada individu dan ekonomi. Perkembangan ekonomi akan tertahan apabila epidemi HIV menyebabkan kemiskinan bagi para penderitanya sehingga meningkatkan kesenjangan yang kemudian menimbulkan lebih banyak lagi keadaan yang tidak stabil.

\section{Dampak Terhadap Tatanan Sosial}

Adanya stigma dan diskriminasi akan berdampak pada tatanan sosial masyarakat. Penderita HIV dan AIDS dapat kehilangan kasih sayang dan kehangatan pergaulan sosial. Sebagian akan kehilangan pekerjaan dan sumber penghasilan yang pada akhirnya menimbulkan kerawanan sosial. Sebagaian mengalami keretakan rumah tangga sampai perceraian. Jumlah anak yatim dan piatu akan bertambah yang akan menimbulkan masalah tersendiri. Oleh sebab itu keterbukaan dan hilangnya stigma dan diskriminasi sangat perlu mendapat perhatian dimasa mendatang.

\section{Bentuk penanggulangan HIV/AIDS}

Sejalan dengan masalah yang dihadapi, Indonesia telah melaksanakan strategi penanggulangan HIV dan AIDS melalui dua periode yang dimuat dalam Strategi Nasional Penanggulangan HIV dan AIDS 1994-2003 dan tahun 2003-2007. Di tahun-tahun 
mendatang tantangan yang dihadapi dalam upaya penanggulangan HIV dan AIDS semakin besar dan rumit sehingga diperlukan strategi baru untuk menghadapinya. Strategi Nasional 2007-2010 (STRANAS 2007-2010) menjabarkan paradigma baru dalam upaya penanggulangan HIV dan AIDS di Indonesia dari upaya yang terfragmentasi menjadi upaya yang komprehensif dan terintegrasi diselenggarakan dengan harmonis oleh semua pemangku kepentingan (stakeholder). Namun strategi ini akan terus mengembangkan kemajuan yang telah dicapai oleh strategi-strategi sebelumnya. Akserelasi upaya perawatan, pengobatan dan dukungan pada orang yang hidup dengan HIV dan AIDS (ODHA) dijalankan bersamaan dengan akselerasi upaya pencegahan baik dilingkungan sub-populasi berperilaku risiko tinggi maupun dilingkungan sub-populasi berperilaku risiko rendah dan masyarakat umum.

Penguatan Komisi Penanggulangan AIDS disemua tingkat dan kelompokkelompok kerja penanggulangan AIDS (Pokja AIDS) di semua sektor diteruskan agar mampu mengkoordinasikan implementasi dari strategi ini di tingkat nasional, regional maupun institusi. Peraturan Presiden No. 75 Tahun 2006 mengamanatkan perlunya peningkatan upaya penanggulangan HIV dan AIDS di seluruh Indonesia. Respons harus ditunjukan untuk mengurangi semaksimal mungkin peningkatan kasus baru dan kematian. Komisi Penanggulangan AIDS di semua tingkat akan semakin kuat. Anggaran dari sektor pemerintah diharapkan juga akan meningkat sejalan dengan masalah yang dihadapi. Sektor-sektor akan meningkatkan cakupan program masing-masing.

Respons utama dalam kurun waktu tahun 1985 - 2002 meliputi pembentukan Kelompok Kerja Penanggulangan AIDS di Departemen Kesehatan, penetapan wajib lapor kasus AIDS, penetapan laboratorium untuk pemerikasaan HIV, penyiapan dan penyebaran bahan Komunikasi, Informasi dan Edukasi (KIE). Surveilans HIV pada subpopulasi tertentu dilakukan demikian pula peningkatan kapasitas tenaga kesehatan dan non-kesehatan dalam menghadapi epidemi serta lahirnya banyak Lembaga Swadaya Masyarakat (LSM) yang peduli terhadap HIV AND AIDS.

Pada tahun 1994 dengan Keputusan Presiden Nomor 36, Pemerintah membentuk Komisi Penanggulangan AIDS (KPA) ditingkat Pusat disusul dengan terbentuknya KPA di beberapa provinsi. Strategi Nasional Penanggulangan HIV AND AIDS (STRANAS 1994) merupakan respons yang sangat penting pada periode tersebut. KPA mulai mengkoordinasikan upaya penanggulangan yang dilaksanakan pemerintah dan LSM. 
Pada Maret dan November 2002 Pemerintah mengadakan Sidang Kabinet Khusus HIV dan AIDS. Pada tahun 2003 STRANAS 2003 -2007 diluncurkan sebagai respons terhadap berbagai perubahan, tantangan dan masalah HIV dan AIDS yang semakin besar dan rumit. Tahun 2004 Program penanggulangan HIV dan AIDS di tempat kerja diluncurkan oleh Departemen Tenaga Kerja dan Transmigrasi dengan pemberlakuan Kaidah ILO. Untuk meningkatkan penyelenggaraan upaya pengurangan dampak buruk (Harm Reduction) penyalahgunaan napza ditandatangi Nota Kesepahaman tentang upaya terpadu pencegahan penularan HIV dan AIDS dan pemberantasan penyalahgunaan NAPZA dengan cara suntik antara Menko Kesra selaku Ketua KPA dan KAPOLRI selaku Ketua Badan Narkotika Nasional (BNN). Untuk memenuhi kebutuhan, maka obat ARV mulai diproduksi di alam negeri oleh perusahaan farmasi pemerintah PT Kimia Farma.

Pada awal 2005 diluncurkan program akselerasi di 100 kabupaten/kota di 22 provinsi, disertai dengan diberlakukannya Sistem Monitoring, Evaluasi dan Pelaporan HIV dan AIDS Nasional. Pada Juli 2006 Institusi KPA Nasional diperbaharui dengan Peraturan Presiden Nomor 75 Tahun 2006 (Perpres 75/2006) yang melibatkan lebih banyak sektor, TNI dan Polri dan masayarakat sipil. Tahun 2006 diakhiri dengan perhitungan estimasi jumlah sub-populasi rawan terhadap penularan HIV tahun 2006 sebagai dasar perencanaan mendatang, penerbitan Peraturan MenkoKesra/Ketua KPA Nasional tentang Kebijakan Penanggulangan HIV AND AIDS melalui Pengurangan Dampak Buruk Penggunaan Jarum Suntik sebagai tindak lanjut dari Nota Kesepahaman KPA-BNN yang ditandatangani pada tahun 2003, dan retrukturisasi sekretariat KPA Nasional.

\section{Metode Penelitian}

Pada makalah ini, penulis menggunakan metode penelitian deskriptif analitis. Pengerjaan ini penulis mulai dengan mengumpulkan data dengan mencari sumber dari internet. Data tersebutlah yang menjadi sumber dari kasus yang ada. Setelah kasus yang diambil dimengerti, maka kemudian dirumuskan inti permasalahannya. Setelah dirumuskan, penulis memilih teori-teori atau konsep-konsep yang dapat penulis jadikan landasan teoritis penelitian, untuk selanjutnya dicarikan solusi pemecahan atas masalah tersebut. 


\section{Pembahasan}

Mengacu pada rumusan masalah yang telah ditentukan pada bagian pendahuluan, maka penulis akan mencoba menganalisis pemecahan masalah berdasarkan poin-poin tersebut.

\section{Apa yang terjadi jika masalah HIV/AIDS tidak segera diatasi?}

Tentu dapat diperkirakan nantinya akan menurunkan angka harapan hidup karena semakin banyak orang yang diperkirakan hidup dalam jangka waktu yang lebih pendek, dan jika masalah ini tidak segera diatasi maka akan semakin banyak pula orang yang tertular penyakit ini dan akhirnya berdampak pada kehidupan sosial dan ekonomi, seperti yang saya tulis dibawah ini.

HIV/AIDS menjadi masalah ditempat kerja karena berdampak:

Langsung: Peningkatan biaya perawatan medis; Meningkatkan biaya tenaga kerja dengan meningkatnya kebutuhan untuk merekrut, melatih dan melatih ulang karyawan; mengurangi jumlah angkatan kerja dan pendapatan para buruh/pekerja.

Tidak Langsung: Menurunkan tingkat produktivitas perusahaan di setiap sektor industri, termasuk pertanian; Mengurangi jumlah tenaga-tenaga terdidik dan terlatih serta berpengalaman; Klaim asuransi karyawan meningkat. Produksi menurun akibat PHK; Terjadi penularan antar karyawan melalui perilaku beresiko tinggi; Memunculkan stigma dan diskriminasi terhadap pengidap HIV yang mengancam prinsip serta hak dasar ditempat kerja, serta menghambat upaya-upaya pencegahan dan penanggulangan.

Sedangkan dampaknya terhadap pekerja adalah: Kehilangan pendapatan dan tunjangan pegawai; Stigma dan diskriminasi; Tekanan terhadap keluarga.

\section{Mengapa Kebijakan dan Strategi Penanggulangan HIV/AIDS Itu Penting?}

Karena untuk mencegah dan mengurangi penularan HIV/AIDS supaya tidak menyebar lebih luas; Karena dapat meningkatkan kualitas hidup ODHA; Karena dapat mengurangi dampak sosial dan ekonomi akibat HIV/AIDS pada individu, keluarga dan masyarakat; Karena merupakan upaya-upaya terpadu dari peningkatan perilaku hidup sehat, pencegahan penyakit, pengobatan dan perawatan berdasarkan data dan fakta ilmiah serta dukungan terhadap ODHA.

\section{Strategi dan Upaya Apa Saja Yang Dilakukan Untuk Penanggulangan HIV/AIDS?}

Untuk mencapai tujuan STRANAS, ditetapkan strategi sebagai berikut: 
Meningkatkan dan memperluas upaya pencegahan yang nyata efektif dan menguji coba cara-cara baru; Meningkatkan dan memperkuat sistem pelayanan kesehatan dasar dan rujukan untuk mengantisipasi peningkatan jumlah ODHA yang memerlukan akses perawatan dan pengobatan; Meningkatkan kemampuan dan memberdayakan mereka yang terlibat dalam upaya pencegahan dan penanggulangan HIV dan AIDS di pusat dan di daerah melalui pendidikan dan pelatihan yang berkesinambungan; Meningkatkan survei dan penelitian untuk memperoleh data bagi pengembangan program penanggulangan HIV dan AIDS; Memberdayakan individu, keluarga dan komunitas dalam pencegahan HIV dilingkungannya; Meningkatkan kapasitas nasional untuk menyelenggarakan monitoring dan evaluasi penanggulangan HIV dan AIDS; Memobilisasi sumberdaya dan mengharmonisasikan pemamfaatannya di semua tingkat.

Upaya-upaya yang dilakukan antara lain: Menyediakan dan menyebarluaskan informasi dan menciptakan suasana kondusif untuk mendukung upaya penanggulangan HIV dan AIDS, dengan menitikberatkan pencegahan pada sub-populasi berperilaku resiko tinggi dan lingkungannya dengan tetap memperhatikan sub-populasi lainnya. Menyediakan dan meningkatkan mutu pelayanan perawatan, pengobatan, dan dukungan kepada ODHA yang terintegrasi dengan upaya pencegahan. Meningkatkan peran serta remaja, perempuan, keluarga dan masyarakat umum termasuk ODHA dalam berbagai upaya penanggulangan HIV dan AIDS. Mengembangkan dan meningkatkan kemitraan antara lembaga pemerintah, LSM, sektor swasta dan dunia usaha, organisasi profesi, dan mitra internasional di pusat dan di daerah untuk meningkatkan respons nasional terhadap HIV dan AIDS. Meningkatkan koordinasi kebijakan nasional dan daerah serta inisiatif dalam penanggulangan HIV dan AIDS.

Pemaksaan Penggunaan Chips (stigma dan diskriminasi) sebagai usaha untuk membatasi ruang kebebasan penderita HIV/AIDS, khususnya dalam area seks bebas, area dimana banyak orang sepertinya belum rela meninggalkannya. Padahal, mereka yang kini menderita HIV/AIDS itu sendiripun terjangkit melalui aktivitas di area seks bebas itu. Apabila ada komitmen untuk menghindari area seks bebas itu, chips untuk penderita HIV/AIDS di Papua tentu saja tidak diperlukan.

\section{Bagaimana memutus rantai penyebaran penyakit itu?}

Secara internasional, pengakuan pentingnya menghargai ODHA sesuai dengan martabatnya sebagai manusia yang mulia juga tertuang dalam deklarasi 
UNGASS (United Nations General Assembly Special Session) pada tahun 2001 dimana Indonesia merupakan salah satu dari 189 negara yang menandatangani deklarasi tersebut. Karena itu sudah seharusnya penanggulangan HIV/AIDS di Papua, dan seantero Indonesia memperhatikan deklarasi itu. Penderita HIV/AIDS sudah semestinya mendapatkan perlakuan yang manusiawi, dan hanya dengan bekerjasama dengan merekalah kita bisa memutus rantai penyebaran penyakit itu.

Upaya pencegahan yang efektif termasuk penggunaan kondom 100\% pada setiap hubungan seks berisiko, semata-mata hanya untuk memutus rantai penularan HIV; Program penanggulangan AIDS di suatu negara bisa berhasil dengan cara merangkul, "memanusiakan" orang-orang dengan HIV/AIDS. Penderita HIV/AIDS yang diterima dengan baik tentu saja akan bersedia ikut dalam usaaha penaggulangan wabah itu. Hanya dengan cara itulah keterlibatan seluruh masyarakat Papua dimungkinkan. Penanggulangan HIV/AIDS yang melibatkan seluruh masyarakat Papua, hanya mungkin terjadi jika promosi anti stigma dan diskriminasi terhadap ODHA dilaksanakan dengan konsisten dan konsekwen seiring dengan gerakan penanggulangan HIV/AIDS. Hanya dengan itulah program penaggulangan HIV/AIDS yang melibatkan seluruh masyarakat Papua dapat terwujud.

\section{Apakah IPTEK Itu Sebaiknya Dihindari?}

Dari tinjauan Alkitab disimpulkan bahwa IPTEK telah dimulai sejak awal sejarah manusia. Manusia memiliki daya cipta IPTEK karena dia diciptakan sebagai gambar Allah dan sebagai pribadi yang berakal budi. Allah sendiri adalah pencipta alam semesta, pendorong dan pencetus ide terhadap lahirnya IPTEK . Allah tidak pernah membatasi daya cipta dan kreasi manusia akan IPTEK. Namun perlu juga dicatat bahwa ide dan tujuan penciptaan IPTEK dan produknya oleh manusia akan dipengaruhi oleh pandangan-pandangannya terhadap Allah , manusia dan alam semesta . Jadi kita tidak perlu menghindari IPTEK tapi yang perlu adalah bagaimana kita memanfaatkan/ menggunakan IPTEK itu secara bertanggung jawab, tentunya kepada Tuhan yang adalah sumber hikmat dan pengetahuan, dan yang menciptakan kita.

\section{Kesimpulan}

Dari uraian pembahasan diatas dapat saya simpulkan sebagai berikut :

Allah sendiri tidak pernah melarang manusia untuk mengembangkan IPTEK. Allah sendiri malah mendukung perkembangan dari IPTEK selama perkembangan 
tersebut masih berada dalam batas kewajaran sesuai dengan nilai-nilai moral dan etika serta berdasarkan Alkitab. Jadi bagaimana sikap kita orang Kristen dalam menyikapi perkembangan IPTEK?

Amsal 1:7 memberikan dasar bagi kita bagaimana harus bersikap terhadap perkembangan IPTEK. Takut Tuhan merupakan dasar pengertian yang benar tentang ilmu pengetahuan dan hikmat dari Tuhan merupakan pegangan supaya kita tidak jatuh dalam pencobaan karena IPTEK. Seringkali iblis memakai IPTEK untuk memperdaya kita melalui tipu muslihatnya. Internet, ponsel, televise, mobil, bahkan apapun bisa membuat kita jatuh dalam pencobaan. Apapun bentuk pencobaannya, sadar atau tidak sadar IPTEK seringkali membuat kita terlena. Untuk menghadapi bisikan-bisikan iblis ini kita harus dapat membekali diri kita dengan iman yang kuat, sebagaimana yang tertulis dalam Efesus 6:10-17. Dengan berdoa, membaca firman Tuhan, dan percaya kepadaNya, kita akan menjadi kebal dengan segala bujukan-bujukan iblis dan kitapun dapat menyikapi perkembangan IPTEK dengan lebih positif.

\section{Saran}

Filter (penyaring) yang paling mendasar adalah kita kembali kepada ajaran firman Tuhan. Keimanan dan ketakwaan yang teguh akan menyaring pengaruhpengaruh negatif dari IPTEK. Hal ini harus dilakukan oleh segenap umat Tuhan.

Dengan penguasaan Iptek, kita tidak akan tertinggal dari negara-negara maju. Bahkan kita sejajar/sederajat dalam percaturan internasional.

Dengan IPTEK akan membawa efisiensi tenaga dan biaya. Alangkah mahalnya biaya yang harus dikeluarkan bila masih menggunakan cara tradisional.

Dengan Iptek kita semakin sejahtera, dengan tidak mengabaikan nilai-nilai kehidupan dan keluhuran.

Dengan IPTEK, manusia yang seluruh hidupnya didasarkan pada iman kepada Yesus akan menggunakan kemampuannya untuk membuat peralatan yang membantu sesamanya bukan membuat senjata atau reaktor nuklir yang menghancurkan sesama dan alam ciptaan Tuhan.

Pemahaman yang benar tentang dampak buruk Iptek bagi umat manusia hendaknya ditanamkan sedini mungkin sehingga hal buruk itu tidak terjadi seperti HIV dan AIDS. 


\section{Referensi}

http://www.sribd.com/doc/29055522/Iman-Kristen-dan-Ilmu-Pengetahuan-serta-

Teknologi

http://www.gotquestions.org/indonesia/kloning-manusia.html

http://www.freewebs.com/mikhaelministry/Iptek\%20dan\%20Iman\%20Kristen.htm

http://www.sabdaspace.org/anti_stigma_dan_diskriminasi

http://www.data.tp.ac.id/dokumen/dampak+positif+dan+negatif+ilmu+pengetahuan +dan+teknologi

http://www.wikimu.com/News/DisplayNews.aspx?id=13060

http://www.sabdaspace.org/anti_stigma_dan_diskriminasi

www.aids-ina.org diakses pada 12 Juli 2011 pada pukul 11.09 pm

http://www.wikimu.com/News/DisplayNews.aspx?id=4311 